\title{
OPINIONS AND KNOWLEDGE ABOUT EAR CROPPING AND TAIL DOCKING AT DOGS IN STARGARD CITY
}

Department of Biotechnology and Animal Husbandry, West Pomeranian University of Technology in Szczecin, Poland

\begin{abstract}
Currently, ear cropping and tail docking are practised surgeries at veterinary clinics. These procedures have been around for centuries with first cases already performed in ancient Rome. The purpose of such body modifications is based on editing ear and tail shapes in a Since 1997, ear cropping and the tail docking is prohibited in Poland, with an exception for when animal's life is endangered and depends upon it. This law also applies to other European countries and the rest of the world, including laws on crossing their boarders with pets recently subjected to this kind of surgery; all of which are regulated by adequate ruling bodies. The aim of this research study was to explode various opinions and level of knowledge on this topic of residents of Stargard city, as well as their personal position with regard to the ear cropping and tail docking at dogs. The research material was collected by direct survey and the selection of respondents was random. Achieved results explicitly pointed at predominating number of negative opinions of performing described surgeries on dogs.
\end{abstract}

Key words: tail docking, ear cropping, health, dog.

\section{INTRODUCTION}

Ear cropping and tail docking are quite controversial surgery procedures conducted at veterinary clinics that aim at forming mentioned above body parts of a dog in a characteristic aesthetic of a given breed (Mills et al. 2016). The first news reporting about this treatment were made already in ancient Rome. Back then, people were superstitious about dog tails and thought that they attracted illnesses, consequently, tails were commonly removed to prevent rabies (Swabe 2007). At the same time, ear cropping and tail docking was performed on canine gladiators, which during fights, could have been exposed for bloody tearing and damage (Mills et al. 2016).

Over the years, ear cropping and tail docking has changed its definition - the subjects to these treatments were now hunting dogs, in order to prevent injuries, especially tail fracture caused by hitting it against bushes while running (Morton 1992; Bennett and Perini 2003a; Ritter 2008). It was a common misconception that the treatment of tail docking in dogs had a strengthening effect on spinal muscles and would increase running speed. In 1796, British government imposed a tax on working dogs that had tails, which resulted

Corresponding author: Karla Karatysz, student of Cynology, Department of Biotechnology and Animal Husbandry, West Pomeranian University of Technology in Szczecin, Janickiego 29, 71-270 Szczecin, Poland, e-mail: karlakaratysz@onet.pl 
in higher willingness to perform this treatment by dog owners (Festa 2009; Mamzer 2018). Even though, the tax was later removed, the treatment maintained its popularity (Morton 1992; Ritter 2008; Bennett and Perini 2003a).

Nowadays, two of the most common reasons, for which dogs have their ear cropped and tail docked, are preserving characteristics of the breed, as well as improvement of the exhibition appearance, which began to be more popular at the end of the 19th century together with the growing number of canine exhibitions (Schmutz and Berryere 2007; Quartarone et al. 2012). In ordinary, households tail docking usually applies to dogs of large breeds. Having a great mass and power has its risk of wounding their own tail against furniture or even other tenants when wagging it unwittingly (Morton 1992; Bennett and Perini 2003a; Ritter 2008).

Arguments put forward by circles approving these treatments, are highly supportive of hygiene and aesthetic standards of a breed. Breeds most vulnerable and exposed to unintentional injuries and tail fractures, often leading to amputation, as well as breeds with a risk of various infections are statistically most often subjected to the surgery. Further arguments of these circles are insensitivity or alleged lack of pain in newborn puppies (Scott 2010), which was proven untrue (Wansbrough 1996). Additionally, they stated that tail docking prevents from the accumulation of excrement around the anus, reducing the likelihood of inflammation and so the appearance of infection (Noonan et al. 1996a).

The reasons, for which this treatment was forbidden are as follows: limiting communication between dogs and between dogs and people, strong pain during the surgery, risk of chronic pain following the surgery and increased sensitivity to pain overall (Mellor 2018). Research conducted by Wansbrough (1996) has knocked down ubiquitous statements that puppies don't feel pain and proved further negative psychological impacts in puppies that went through the tail decking procedure. This argument has been used multiple times against supporters who praise and promote tail docking as positive and deny any painful effects of this treatment that could have impact a dog's entire future (Wansbrough 1996). Extensive use of tail in body language, which is an integral part of communication between all dogs, proves the enormous significance of the tail. Research shows that tail docking can largely interrupt in reading and interpretation of behaviour of dogs in a group. This includes both, expressing positive and negative emotions or moods which they are playing big roles in ensuring the welfare of dogs. Communication difficulties can accompany animals through their entire life, which argues against the misbelief that the tail is only an unnecessary addition (Mellor 2018).

Discussion about morality and necessity of the surgeries still lasts in many countries as well as all sorts of social media platforms. The opinions here seem radically different. Veterinary associations and the pro - animal groups usually support and encourage prohibition of these practices. Breeders and associations of pure - bred dogs oppose to them (Bennett and Perini 2003a,b).

In Poland, ear cropping and tail docking has been entirely forbidden since 1997, except for cases, in which life of a dog is endangered. This rule regulates provisions of all sorts of kennel clubs, such as FCl (Federation Cynologique Internationale), AKC (American Kennel Club), UKC (United Kennel Club) or Kennel Club in Poland (ZKwP). They describe conditions of the performers at all show categories: pure - bred domestic, international and others 
organised by these institutions with dogs subjected to ear cropping and tail docking surgeries. In relation to the amendment of the acts of animal protection (DZ.U. z 2011 r., nr 230, poz. 1373), in art. 6, act 2, point 1, Main management board of Kennel Club in Poland has made two decisions:

1. All dogs born after 01.01.2012 must have natural ears and tail.

2. Prohibition of dogs with cropped ears and docked tails born after 01.01.2012 from exhibition, with the exception when the treatment was performed with the respect for art. 27 acts of the protection of animals (Zarząd Główny ZKwP 2015; Mamzer 2018).

Similar provisions, entirely or in part forbidding ear cropping and tail docking, were implemented in countries which ratified European Convention for the Protection of Pet Animals from 1987 (Council of Europe 1987). To the countries entirely forbidding ear cropping and tail docking belong: Poland, Austria, Belgium, Greece, Netherlands, Norway, Portugal and eighteen other countries. Countries in which ear cropping is prohibited but tail docking is allowed are: the Czech Republic, France, Morocco, Monaco and Hungary. Countries in which ear cropping and tail docking is prohibited, excluding hunting dogs subjected to this treatment exclusively on the tail are: Croatia, Latvia, Germany, Serbia, Slovakia and Italy. Whereas the list of countries, which completely permit ear cropping and tail docking covers countries like: Armenia, Azerbaijan, Russia and Uzbekistan. An interesting law referring to these surgeries was enforced in Kyrgyzstan, where ear cropping and tail docking is completely forbidden except for one breed - Central Asian Shepherd Dog (Zarząd Główny ZKwP 2019). In all countries provisions differ in relation to tail docking. Commonly, however not applying to countries fully accepting ear cropping and tail docking and countries with a complete or partial prohibition on either of the surgeries, is a total ban of the ear cropping in dogs.

Apart from different regulations regarding ear cropping and tail docking in EU countries and outside, there is a law which entirely forbids entrering countries with dogs after these surgeries. This law applies fully to Switzerland (Zarząd Główny ZKwP 2019), whereas it is possible to enter Portugal only with a valid certification from the veterinary surgeon that confirms if the surgery was conducted to health purposes (Rozporządzenie (WE) nr 998/2003 Parlamentu Europejskiego i Rady). Border crossing with a dog after ear cropping and/or tail docking is entirely legal and allowed in Poland (Turoń et al. 2015; Zarząd Główny ZKwP 2015).

The aim of this research is to record a number of opinions of residents of Stargard about ear cropping and tail docking in dogs, in particular, among people without extensive knowledge of this work in cynological sciences.

\section{MATERIAL AND METHODS}

The research material was obtained anonymously through the method of diagnostic survey and the technique of the direct interview in paper form. The selection of respondents had a random character and involved 103 residents of Stargard (west pomeranian voivodeship, PL, $53^{\circ} 20.2032^{\prime} \mathrm{N} 15^{\circ} 2.994^{\prime} \mathrm{E}$ ). This research was realised in 2017. Below is the implemented questionnaire, which consists of 8 , either opened or closed, questions.

The questionnaire contained the following questions:

1. Do you have a dog?

2. Do you like dogs with ear cropping and/or tail docking? 
3. Do you accept ear cropping and tail docking surgeries?

4. Why do you accept ear cropping and tail docking?

5. Would you perform ear cropping and tail docking on your dog or do you have it in plans?

6. Why aren't you accepting of ear cropping and/or tail docking?

7. In your opinion, is ear cropping and/or tail docking in dogs a creation of fashion or a necessity (e.g. health issues)?

8. Do you think that, in Poland, ear cropping and tail docking in dogs should be legal? Collected data was drawn up in Microsoft Excel.

\section{RESULTS AND DISCUSSION}

The examined population consisted of persons between 18 and 70 years of age. Out of all respondents, 53 had a dog/dogs (52\%) and 50 weren't dog owners (48\%). Nineteen respondents (including ten dog owners) expressed preference in dogs subjected to the surgery of ear cropping or tail docking. $82 \%$ of people, who did not have any education in cynological sciences, were not accepting of ear cropping and/or tail docking in dogs. The statistical results concerning opinions of the respondents about the surgeries were introduced in Table 1. The predominant opinion - 'does not accept ear cropping and/or tail docking' was mostly advocated by negative health consequences or a caprice of careless dog owners.

Table 1. Opinions of respondents

\begin{tabular}{lcc}
\hline & Dog owners & Not owning dogs \\
\hline $\begin{array}{l}\text { Accepts ear cropping and tail } \\
\text { docking }\end{array}$ & 10 & 9 \\
\hline $\begin{array}{l}\text { Does not accept ear cropping } \\
\text { and tail docking }\end{array}$ & 43 & 41 \\
\hline
\end{tabular}

Respondents were also asked about their attitude towards legalisation of ear cropping and tail docking surgeries at veterinary clinics in Poland (Table 2). The majority of respondents $(76 \%)$ were against legalisation of conducting these treatments in Poland. Seventeen participants without dogs and eight owners were in favour of legalising shortening the tail and/or ears.

Table 2. Legalisation of ear cropping and tail docking in Poland.

\begin{tabular}{lcc} 
& Dog owners & Not owning dogs \\
\hline Agree & 8 & 17 \\
\hline Disagree & 45 & 33 \\
\hline
\end{tabular}

$69 \%$ respondents think, that ear cropping and tail docking in dogs is purely an invention of fashion; only four respondents recognised these treatments for their health benefits. Dogs remain an important fraction of society in many countries worldwide. Numerous groups of supporters of ear cropping and tail docking in dogs claim that accompanying the surgeries 
pain has little effect on individual dogs (Mills et al. 2016). However, research conducted through Mills et al. (2016) confirms that perceiving that dogs feel pain during the procedure as well as unnaturalness of their appearance affects the decision making by owners about performing this practice, even for health purposes. Awareness of pain experienced by dogs during these treatments also has a significant effect on human population being against legalisation of conducting the surgeries in Poland. The purposes of conducted piece of research were: the evaluation of public awareness about ear cropping and tail docking, the establishment whether body modifications in dogs influence how the pets are perceived, and public reputation of owners who have agreed to performing this surgery. Overall, the results explicitly pointed at the negative perception of ear cropping and tail docking surgeries on dogs among the interviewed.

In spite of persistent actions taken by numerous groups of supporters against these surgeries and despite existing harmful effects of shortening the tail or ears and even legal prohibitions, it is still possible to observe dogs subjected to the surgeries in many countries. Analysis conducted by Nolte in 2006 , demonstrated, that despite German law, dogs of other breeds were also surrendered to these practices, in particular, Doberman breed, which, by their aesthetic standards, are expected to have their ears and tails shortened. Moreover, these illegal surgeries were often conducted by the same veterinary surgeons. A lot of doubts given the same medical causes usually described at different animals enrolled in one veterinary hospital, the breed, for which the breed standard predicts ear cropping and tail docking and belonging to the same breeder (Nolte 2006).

\section{CONCLUSION}

Ear cropping and tail docking in dogs has been accompanying people around the world for centuries. It is hard for say, how much, for sure, they influence dogs' life. However, there are more and more research studies appearing to confirm the adverse impact on the welfare of dogs (Wansbrough 1996; Nolte 2006; Mellor 2018). Approvals of conducting these treatments have various basis. Although opinions often contradict each other, still, the final choice in relation to operating dogs belongs to the owners. Frequently, performing ear cropping or tail docking is supported by important health considerations and sometimes ratified by breed's standards or the appearance of a dog.

Since the ban on ear cropping and tail docking was introduced (1.01.2012) in Poland, the numbers of procedures did not fall significantly, which means that they still take place illegally. They are usually conducted in dog owners' homes or clinics, who's keepers are not discouraged by the potential legal consequences.

More than half of respondents (about 60\%) disagreed with ear cropping and tail docking after getting acquainted with information about the methods of the surgeries and their legal reasons (mainly health issues) as well as dangers associated with conducting the surgery on their own initiative by owners, who often aren't following regulations being obligatory in our country, entirely or partly changed mind what can attest to the low awareness of the society in this subject. 


\section{REFERENCES}

Bennett P.C., Perini E. 2003a. Tail docking in dogs: a review of the issues, https:// 10.1111/j.1751-0813.2003.tb11473.x, access: 02.02.2021.

Bennett P.C., Perini E. 2003b. Tail docking in dogs: can attitude change be achieved?, https:// 10.1111/j.1751-0813.2003.tb12575.x, access: 02.02.2021.

Council of Europe. 1987. European convention for the protection of pet animals, https://conventions.coe.int/Treaty/en/Treaties/Html/125.htm, access: 03.02.2021.

Festa L. 2009. Person, animal, thing: The $1796 \mathrm{dog}$ tax and the right to superfluous things. EighteenthCent. Life Durham 33(2),1-44.

Mamzer H. 2018. Czy jest możliwy uwspólniony dobrostan ludzi i innych zwierząt? [ls the shared welfare of humans and others animals possible?] Życie Wet. 93(10), 673-678. [in Polish]

Mellor D.J. 2018. Tail Docking of Canine Puppies: Reassessment of the Tail's Role in Communication, the Acute Pain Caused by Docking and Interpretation of Behavioural Responses, https://10.3390/ani8060082, access: 02.02.2021.

Mills K.E., Robbins J., Keyserlingk M.A.G. von. 2016a. Tail Docking and Ear Cropping Dogs. PLoS One 11(6), e0158131, https://doi.org/10.1371/journal.pone.0158131, access: 15.06.2020.

Morton D. 1992. Docking of dogs: practical and ethical aspects. Vet. Rec. 131, 301-306

Nolte I. 2006. Analysis of veterinary certificates on tail docking in dogs. Dtsch. Tierarztl. Wochenschr. 113(3). [in German]

Noonan G.J., Rand J.S., Blackshaw J.K. 1996. Tail docking in dogs: a sample of attitudes of veterinarians and dog breeders in Queensland. Aust. Vet. J. 73, 86-88.

Rozporządzenie (WE) nr 998/2003 Parlamentu Europejskiego i Rady z dnia 26 maja 2003 r. w sprawie wymogów dotyczących zdrowia zwierząt, stosowanych do przemieszczania zwierząt domowych o charakterze niehandlowym, i zmieniające dyrektywę Rady 92/65/EWG. Dz.U. z 13.06.2003, nr 146. [in Polish]

Quartarone V., Voslářová E., Russo M., Doleželová P., Passantino A. 2012. A comparison of laws preventing unnecessary canine cosmetic surgery in Italy and in the Czech Republic. Acta Vet. Brno 81,83-88.

Ritter C.R. 2008. Animal rights. Edina Minnesota (MN), ABDO Publishing.

Schmutz S.M., Berryere T.G. 2007. Genes affecting coat colour and pattern in domestic dogs: a review, https:// 10.1111/j.1365-2052.2007.01664.x, access: 03.02.2021.

Scott J. 2010. Tail docking and ear cropping. A comment. The Canadian Veter. J. 51(10).

Swabe J. 2007. Veterinary Dilemmas: ambiguity and ambivalence in human-animal interaction, in: Companion animals and us: Exploring the relationships between people and pets, eds. A. Podersbeck., E. Paul, J. Serpell, Cambridge University Press, 292-312.

Turoń K., Juzek M., Czech P. 2015. Praktyczne porady dotyczące niezarobkowego przewozu zwierząt domowych na terenie Unii Europejskiej - aspekt prawny [Practical advice about the non-profit transport of pets in the European Union - legal aspect.]. Zesz. Nauk. Politech. Śl., Transp. 86, 99-107. [in Polish]

Wansbrough R.K. 1996. Cosmetic tail docking of dogs, https://10.1111/j.1751-0813.1996.tb13737.x, access: 2.02.2021.

Zarząd Główny Związku Kynologicznego w Polsce. 2015. Komunikat ZG ZKwP dotyczący zakazu wystawiania psów z ciętymi uszami i / lub ogonami, http://legnica.zkwp.pl/komunikat-zg-zkwp-dotyczacy-zakazu-wystawiania-psow-z-cietymi-uszami-ilub-ogonami/, access: 15.06.2020. [in Polish]

Zarząd Główny Związku Kynologicznego w Polsce. 2019. Aktualny stan prawny dotyczący cięcia uszu i ogonów w krajach należących do sekcji europejskiej FCl (sekcja obejmuje 51 krajów), https://www.zkwp.pl/Ciecie_uszu_i_ogon\%C3\%B3w_-_kraje_-_lipiec2019.pdf, access: 15.06.2020. [in Polish] 


\section{OPINIE I WIEDZA MIESZKAŃCÓW STARGARDU NA TEMAT KOPIOWANIA USZU I OGONA U PSÓW}

Streszczenie. Obecnie kopiowanie jest zabiegiem chirurgicznym przeprowadzanym w klinikach weterynaryjnych. Pierwsze zabiegi wykonywane były już w starożytnym Rzymie. Cel przeprowadzanego zabiegu opiera się na ukształtowaniu małżowiny usznej oraz ogona w specyficzny dla danej rasy sposób, tak aby uwidocznić kształty ciała psa. W Polsce kopiowanie uszu i ogona jest całkowicie zabronione od 1997 r., z wyjątkiem sytuacji, w których występuje zagrożenie życia psa. Prawo to dotyczy również innych krajów Europy i świata, w których odpowiednie organy uregulowały możliwość przeprowadzania zabiegu kopiowania uszu i ogona, jaki również przekraczania granic państw ze zwierzętami poddanymi wcześniej temu zabiegowi. Celem niniejszej pracy było poznanie opinii oraz wiedzy mieszkańców Stargardu nt. kopiowania uszu i ogona u psów. Materiał zebrano metodą sondażu bezpośredniego, a dobór respondentów miał charakter losowy. Uzyskane wyniki wykazały, że większość opinii na temat przeprowadzania zabiegu u psów była negatywna.

Słowa kluczowe: skracanie uszu, skracanie ogona, zdrowie, pies. 
